\title{
COMUNICAÇÃo
}

\author{
[Communication]
}

\section{Pesquisa de anticorpos para IBR em amostragem de demanda no Estado de Minas Gerais, 1990-1999}

[Survey of antibody against IBR on demanding sampling in Minas Gerais State, 1990-1999]

\author{
M.A. Rocha, A.M.G. Gouveia, Z.I.P. Lobato, R.C. Leite \\ Escola de Veterinária da UFMG \\ Caixa Postal 567 \\ 30123-970 - Belo Horizonte, MG
}

Recebido para publicação em 16 de outubro de 2000

Recebido, após modificações, em 25 de setembro de 2001

E-mail: rochama@vet.ufmg.br

A vulvovaginite pustular infecciosa das vacas e a balanopostite infecciosa dos touros são doenças genitais de bovinos causadas pelo herpesvírus bovino 1 (HVB-1). Antes de 1900 essas manifestações tinham sido detectadas na Europa, mas sua importância econômica era subestimada, uma vez que o único sinal clínico reconhecido era uma breve interferência sobre a eficiência reprodutiva (Miller et al., 1991). Na década de 1950, pesquisadores americanos evidenciaram o papel do HVB-1 como causador também de uma grave infecção do trato respiratório superior de bovinos, a rinotraqueíte infecciosa bovina, conhecida pelas iniciais IBR (infectious bovine rhinotracheitis) (Madin et al.,1956).

Testes laboratoriais têm demonstrado a presença da infecção pelo HVB-1 em rebanhos bovinos de diversos estados brasileiros com percentuais variando de $27,1 \%$ a $85,7 \%$ de animais soropositivos nos rebanhos estudados (Alice, 1978; Castro,1988; Filho et al.,1997; Melo et al.,1997; Pelegrini, 1993; Rocha et al.,1995). No entanto, os testes atualmente disponíveis no Brasil não permitem a diferenciação entre animais que apresentam anticorpos devido à vacinação ou à infecção natural (Rocha, 1999). Desde 1990, exames para detecção de anticorpos anti-HVB-1 (micro soroneutralização) vêm sendo realizados como rotina no laboratório de virologia animal da Escola de Veterinária da UFMG. O presente trabalho teve o objetivo de estudar a frequiência de bovinos soropositivos para o HVB-1 no Estado de Minas Gerais, a partir de amostragem de demanda recebida espontaneamente no período de 1990 a 1999. Adicionalmente, buscou-se avaliar a dinâmica da procura pelo serviço de diagnóstico laboratorial da doença em relação ao número de animais e de município testados durante o referido período.

Foram testados 5511 soros sangüíneos de bovinos, provenientes de propriedades particulares localizadas em 335 municípios do Estado de Minas Gerais. Os soros foram encaminhados espontaneamente (amostragem de demanda) ao laboratório para diagnóstico de IBR, por meio de pesquisa de anticorpos para o HVB-1. Os soros foram inativados a $56^{\circ} \mathrm{C}$ por 30 minutos e submetidos às técnicas de micro soroneutralização ou ELISA. A micro soroneutralização foi realizada em microplacas de 96 poços, cada soro testado em duplicata. Utilizou-se a amostra de vírus padrão Los Angeles com título de 100 TCID $_{50}$

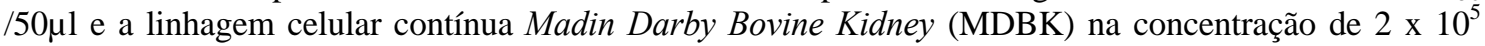
células $/ \mathrm{ml}$. Os títulos obtidos foram expressos como o inverso da maior diluição de soro que inibiu totalmente o efeito citopático do vírus-padrão, sendo considerados positivos os soros com título superior a 4. Os testes de ELISA foram realizados utilizando-se o kit HerdChek® (IDEXX (Maine, USA), segundo protocolo do fabricante. 


\section{Rocha et al.}

A Tab. 1 apresenta a distribuição anual dos exames e número de municípios do Estado de Minas Gerais que apresentaram pelo menos uma sorologia positiva para HVB-1, demonstrando a ampla ocorrência de resultados positivos. Entre os 335 municípios remetentes de soros para diagnóstico sorológico, 313 $(93,4 \%)$ apresentaram pelo menos um bovino com sorologia positiva. A Tab. 2 apresenta o número de resultados sorológicos para HVB-1 estratificado por ano. No período 1990 - 1999 foram testados 5511 soros, dos quais $3206(58,2 \%)$ apresentaram anticorpos contra o HVB-1. O grande número de soros testados em 1990 (717) deveu-se à grande remessa de soros de uma única propriedade. Entretanto, em termos percentuais, a quantidade de bovinos com sorologia positiva (131) foi a menor encontrada $(18,3 \%)$

Tabela 1. Distribuição anual dos municípios que apresentaram pelo menos um bovino soropositivo (soroneutralização e ELISA) para HVB-1 em amostragem de demanda, Minas Gerais, 1990 a 1999

\begin{tabular}{cccc}
\multirow{2}{*}{ Ano } & \multicolumn{3}{c}{ Municípios } \\
\cline { 2 - 4 } & \multirow{2}{*}{ Municípios testados } & Municípios positivos \\
\cline { 3 - 4 } & 3 & 3 & $\%$ \\
\hline 1990 & 11 & 6 & 100,0 \\
1992 & 8 & 5 & 62,6 \\
1993 & 12 & 11 & 91,7 \\
1994 & 14 & 14 & 100,0 \\
1995 & 29 & 29 & 100,0 \\
1996 & 62 & 58 & 93,6 \\
1997 & 91 & 87 & 95,6 \\
1998 & 105 & 100 & 95,2 \\
1999 & 335 & 313 & 93,43 \\
Total & &
\end{tabular}

${ }^{1}$ Dados referentes a 1991 não disponíveis.

Os soros estudados não representam amostragem estatística da população bovina do Estado, já que não foram coletadas para este fim e sim enviadas espontaneamente por criadores e veterinários em busca de diagnóstico laboratorial. Assim, considerando-se a amostragem como demanda espontânea, pode-se observar que entre os anos de 1995-1996 e 1996-1997 houve aumento acentuado (4,4 e 3,4 vezes, respectivamente) no número de animais testados (Tab.2). Observa-se também, a partir de 1995, aumento do número de municípios que remeteram soros para exames. Este aumento anual foi de aproximadamente duas vezes entre 1995-1996 e 1996-1997 (Tab. 1). Os dados indicam aumento de interesse entre os criadores e veterinários no diagnóstico laboratorial da IBR a partir da metade da década de 90. Os soros pertencentes a este estudo raramente vieram acompanhados de relato clínico adequado. Assim, foi impossível relacionar os achados sorológicos aos sintomas compatíveis com a doença clínica. Em todo caso, a presença de anticorpos assegura apenas que o animal manteve contato com o agente em algum momento de sua vida, isto é, nessa situação foi impossível diferenciar resultados sorológicos positivos ocasionados por infecção ou por vacinação, em função da inexistência de testes que permitam tal diferenciação no mercado brasileiro. Vacinas marcadas permitem a diferenciação entre animais vacinados e infectados, e parecem ser mais indicadas principalmente para uso em touros de centrais de inseminação e em programas de erradicação do HVB-1 (Flores et al., 1993; van Oirschot et al., 1996). No entanto, até o momento não há essa opção no mercado brasileiro. Recomenda-se, portanto, que a sorologia para pesquisa de anticorpos para HVB-1 seja realizada em amostras pareadas de soro, coletadas em intervalos de 21 a 30 dias, sempre que possível em associação com a pesquisa do agente (isolamento viral e/ou PCR) em amostras clínicas, como suabes nasal e vaginal, fragmentos de fetos abortados e sêmen. 
Tabela 2. Distribuição anual dos testes de soroneutralização e ELISA ${ }^{1}$ realizados para detecção de anticorpos contra HVB-1 em amostragem de demanda no Estado de Minas Gerais, 1990 a 1999

\begin{tabular}{cccc}
\hline \multirow{2}{*}{ Ano } & \multirow{2}{*}{ Soros testados } & \multicolumn{2}{c}{ Soros positivos } \\
\cline { 3 - 4 } & & $\mathrm{N}$ & $\%$ \\
\hline 1990 & 717 & 131 & 18,3 \\
1992 & 68 & 15 & 22,11 \\
1993 & 57 & 11 & 19,3 \\
1994 & 98 & 37 & 37,8 \\
1995 & 64 & 51 & 52,7 \\
1996 & 287 & 254 & 88,5 \\
1997 & 991 & 600 & 60,5 \\
1998 & 1678 & 1062 & 63,3 \\
1999 & 1551 & 1045 & 67,4 \\
Total & 5511 & 3206 & 58,17 \\
\hline Testes de ELISA realizados a partir de 1998 \\
Dados referentes ao ano de 1991 não disponíveis.
\end{tabular}

Palavras-chave: Bovino, IBR, BHV-1, serologia, diagnóstico

\begin{abstract}
A survey of antibody to IBR was performed by serum neutralization test and ELISA in cattle sera supplied on demand sampling in Minas Gerais State, during the period of 1990 to 1999. Out of 5511 tested samples, 3206 (58.2\%) were positive and out of 335 evaluated counties, 313 (93.4\%) had at least one positive result. It was noted an increasing interest by farmers and practitioners on IBR serological diagnosis since 1995, when the amount of animals and counties submitted to test greatly increased in comparison with past years. The role of serology in adequate diagnosis of IBR is discussed.
\end{abstract}

Keywords: Cattle, IBR, BHV-1, serology, diagnosis

\title{
REFERÊNCIAS BIBLIOGRÁFICAS
}

ALICE, J.F. Isolamento do vírus da rinotraqueíte infecciosa bovina (IBR) no Brasil. Rev. Bras. Biol., v.38, p.919920, 1978

CASTRO, R.S. Desempenho reprodutivo até 60 dias de gestação em doadoras de embriões bovinos, frente à infecção por diarréia bovina a vírus, herpesvírus bovino tipo 1, leucose bovina e língua azul, em Minas Gerais. Belo Horizonte: Escola de Veterinária da UFMG, 1988. 93p. (Dissertação, Mestrado)

FILHO, I.R.B., KRÜGER, E.R., SOUZA, J.F. et al. Incidência de bovinos soropositivos para o vírus da rinotraqueíte bovina no município de Palotina-PR. In: Congresso Brasileiro de Medicina Veterinária, 25, 1997, Gramado. Anais... Gramado, 1997. p. 171.

FLORES, E.F., OSÓRIO, F. A, ZANELLA, E.L. et al. Efficacy of a deletion mutant bovine herpesvirus-1 (BHV-1) vaccine that allows serologic differentiation of vaccinated from naturally infected animals. J. Vet. Diag. Invest., v.5, p.534-540, 1993.

MADIN, S.H., YORK, C.J., MCKERCHER, D.G. Isolation of infectious bovine rhinotracheitis virus. Science, v.124, p.721-722, 1956.

MELO, C.B., OLIVEIRA, A.M., FIGUEIREDO, H.C.P. et al. Prevalência de anticorpos contra herpesvírus bovino 1, vírus da diarréia bovina a vírus e vírus da leucose enzoótica bovina em bovinos do Estado de Sergipe, Brasil. Rev. Bras. Reprod. Anim., v.21, p. 160, 1997.

MILLER, J.M., WHETSTONE, C.A., van der MAATEN, M.J. Abortifacient property of bovine herpesvirus type 1 isolates that represent three subtypes determined by restriction endonuclease analysis of viral DNA. Am. J. Vet. Res. v.52, p.458-461, 1991. 


\section{Rocha et al.}

PELEGRINI, A.O. Detecção de anticorpos para herpesvírus bovino tipo 1, vírus da diarréia bovina a vírus (BVD) e vírus da língua azul em um período de três anos em gado de corte no Pantanal Matogrossense, M.S. Rev. Bras. Reprod. Anim., v.18, p.112-115, 1993.

ROCHA, M.A. Diagnóstico da rinotraqueíte infecciosa bovina (IBR). Rev. Bras. Reprod. Anim., v.23, p.535-539, 1999.

ROCHA, M.A., GOUVEIA, A.M.G., LEITE, R.C. Detecção de anticorpos HVB1 em touros de uma central de sêmen - soroneutralização e isolamento no sêmen. Rev. Bras. Reprod. Anim., v.19, p.181-186, 1995.

van der OIRSCHOT, J.T., KAASHOEK, M.J., RIJSEWIJK, F.A. Advances in the development and evaluation of bovine herpesvirus 1 vaccine. Vet. Microb., v.53, p.43-54, 1996. 